\title{
Philosophy of Education: A Tool for National Development?
}

\author{
Godwin Abiogu \\ Department of Educational Foundations, University of Nigeria, Nsukka, Nigeria \\ Email: abiogu@yahoo.com
}

Received 15 May 2014; revised 20 June 2014; accepted 4 July 2014

Copyright (C) 2014 by author and Scientific Research Publishing Inc.

This work is licensed under the Creative Commons Attribution International License (CC BY). http://creativecommons.org/licenses/by/4.0/

(c) (i) Open Access

\section{Abstract}

This paper is an exposition on the theoretical and practical relevance of educational philosophy to national development. It postulated that philosophical ideas have been responsible for shaping the development of societies through the channels of education. Contextually, the concepts of "education", "philosophy", and the nexus between philosophy and philosophy of education were articulated. The term "development" was analyzed. The paper examined philosophy of education as a tool in the development of the nation from the perspective of men's capacity to think more critically and reflectively. Seen also from men's pursuit for wisdom, the good life, educational policy formulation and the intellectual development of the teacher and the learner in their educational practice, relevant implications and recommendations were proffered based at the end of the paper.

\section{Keywords}

Philosophy of Education, National Development, Channels of Education, Policy Formulation, The Teacher and the Learner

\section{Introduction}

Education is believed to be the bedrock of any country's development. It is considered as the cornerstone for meaningful and sustainable growth development and achievement in art, science and technology. Arguing in the same direction, Umo (2005), had affirmed that, worldwide, education has been recognized as a catalyst for achieving socio-economic, scientific and technological development. For instance, Federal Government of Nigeria (2004) declared in its National Policy on Education that education is an instrument par excellence for achieving national development. In other words, any meaningful growth and development of any country must be preceded by a sound educational planning. Since education constituted an indispensable aspect of social real- 
ities of a nation, it is of cardinal importance to any society.

From the above postulations, one could now see that education is not just a mere discipline, but a philosophical force of its own with positive implications for human development. Obviously, any such education without a philosophy may not achieve its envisioned end for national development. Arguably, any education that is devoid of some philosophy would tantamount to the anomaly of a lively tortoise moving around without its carapace. Thus it is the intention of this paper to prove how education energized by philosophy can form the basis for national development. To this end, how can the term "philosophy" be understood?

\subsection{What Is Philosophy?}

The intellectual endeavour of various schools of thought to understand the term "philosophy” has never been an easy task. According to Akinpelu (2005) Plato (427 BC-347 BC) and other disciples of Socrates (470 BC-399 BC) corroborated in their writing that, “Socrates preferred not to call his students wise men”. He rather called them by a more modest and apropos title, namely: "lovers of wisdom.” This lends much credence to the etymology of the word "philosophy", which is coined from two Greek words: Philo (love) and Sophia (wisdom or knowledge). The combination of the two Greek words resulted in the term, Philosophia, meaning love of wisdom. Philosophic wisdom is an intellectual engagement which enables a man, to a large extent assess his ideals as well as his life aspirations. It makes him understand the rationale for accepting certain ideals in life and why he ought to accept them in the first place.

For Okoh (1998), philosophy is a method of reflective and constructive thinking and reasoned inquiry. On the part of Oroka (2010), philosophy is a philosophic wisdom and activity concerning the existence of things around us. It concerns with what is, and why what is, is; as well as a man's place in the universe of things. Philosophy is therefore perceived as an attitude towards life, which makes it (life) become more intelligent, more meaningful and purposeful. It achieves this by clarifying, justifying and verifying issues through criticism of concepts and principles. Philosophy is hereby considered as that which distinguishes reason from evidence of things, and gives purposeful direction to life. In the light of this, is there any relationship between philosophy and philosophy of education? If there is none why, but if there is, how?

\subsection{The Nexus between Philosophy and Philosophy of Education}

Philosophy of education is at the very centre of the whole educational enterprise. To state the point more clearly, Mango (2011) highlighted that philosophy of education played a central role by being interested in the views of the other foundations, as well as the various methods they used by employing the tools and techniques of philosophy. Buttressing the above, Reid (1972) averred that philosophy of education was the use of philosophical instruments, and the application of philosophical methods to educational questions. It inquires how the results of such philosophical thinking are related to education. This obviously presents philosophy of education as an intelligent thinking about education. Philosophy of education like philosophy itself performs many tasks. The tasks advanced by various philosophers of education as Shaaba (2010) noted, depended on their conception of the aims of education intended.

For instance education for Plato (427 BC-347 BC) aims primarily at political and social cohesion of the nation it serves. Good education promotes the good conduct which in turn breeds peace and concord necessary for building a nation. Analytically, the aim of education from Plato's philosophical thought is to put a man in the right order, to show him the right path and to instill in him the spirit of dedication towards social stability and cohesion. Certainly, this is achievable only when people are educated according to their talents and natural potentials in the society. Such educative method will lead to the knowledge of different areas of sciences for the development of society. The findings of these different areas of sciences are co-ordinated by philosophy, while philosophy of education interprets such findings as they bear on education. Thus, philosophy of education by using the tool of critical analysis, provides a foundation for the development of a man and his society. From the foregoing, what does development imply for a man who is the central subject matter in education, in philosophy and in philosophy of education?

\section{Development for Man as a Human Person}

Philologically, development is multi-dimensional in its meaning. It has economic, social, political, cultural, hu- 
man or personal dimensions. Babarinde and Farayola (2005) highlighted that, development involves increase in the quality and quantity of life of a people. It includes gradual removal of poverty, unemployment, social inequalities, bad leadership, monopolization of opinion by the government, and of the negative practices which unfortunately have become the major characteristics of human society. This view presents development as being both qualitative and quantitative.

In the same wake of thought, Ogundowole (2004) described meaningful development as self-realization which implies the use of the resources of geophysical, imagination and unprecedented ingenuity to achieve overall societal objectives. In a way it might be inadequate to conceive development purely as an economic affair. It is to be considered as an overall social process which is dependent upon the outcome of man's endeavour to manipulate his natural environment. The target of the developmental process is the human person himself. He is to be equipped with the necessary skills, knowledge and attitudes to enhance his creative potentials, for his participation in the improvement of his physical environment.

In other words man is expected to be an active participant in the process of development. Such expectation stems from the premise that man is central both in education and development, just like education is an important tool to development. If man is to be fully equipped to take his own development in his hands, then philosophy of education can be a major tool to enhance man's role in development. Since it can be established that philosophy and education are decisive allied factors in development, a review of the importance of philosophy of education to man in the practice of education might not be out of place but adequate, as this paper inquires about the relevance of philosophy of education in national development.

\section{The Role of Philosophy of Education in National Development}

Philosophy of education broadens the mind by enabling it understand many different ways of viewing things in the order of human existence. It provides man with an insight on how certain philosophers of various date and time approached the problems of life from generation to generation. Their methods of approach help man to understand different ways of perceiving truth and reality. This is relevant to national development because it would enable the country to solve the pervading tribal, ethnic and religious problems which are formidable obstacles to national development.

\subsection{Philosophy of Education in the Development of Man's Thinking Capacity}

Philosophy of education trains one to think more critically and reflectively, and with that one can clear away such confusions which personal interests and prejudiced emotions may generate. Philosophy of education as Donald (1994) posited frees one from the instinctive tendency to interpret everything in terms of self. By attempting to think of the universe as it is, rather than simply as how it affects one, one enlarges oneself by leaving behind as much as possible the rationalization of his hopes and fears, as well as his preconceptions and prejudices. On a stretch of imagination, when man enlarges himself he also enlarges the sphere of his actions and affections, which is necessary for national development.

\subsection{Philosophy of Education for Pursuit of Wisdom}

In an early attempt to answer the question of what is philosophy, it ended up in the interpretation of philosophy as love of wisdom, and that Socrates (470 BC-399 BC) preferred calling his students "lovers of wisdom". If philosophy as a term means "love of wisdom" or pursuit of wisdom and there is nexus between philosophy and philosophy of education, then the idea of seeking for wisdom is central in the primary role of philosophy of education, as it prescribes and teaches that which is worthwhile for people to follow. The continuous pursuit and seeking for knowledge and understanding have been the core practice of philosophy. Indeed, the essence of knowledge pursuit and understanding, must have informed Pythagoras (C. 600 BC) to distinguish three kinds of lives or divisions of people, as Lavine (1984) articulated in his philosophic quest. Here Pythagoras alleged that there are three different kinds of people who go to Olympian Games.

The lowest is made up of those who go there to buy and sell to make profit. Next are those who go there to compete to gain honours. Best of all, Pythagoras noted, are those who come as spectators, who reflect upon and analyze what is happening. They insist in constant pursuit of knowledge. Of these three, the spectators illustrate the activity of philosophers who are liberated from daily life and its infections in the course of continuous pur- 
suit and seeking for knowledge. Their interest in the games lies in the constant disposition to spurn fame and profit, and go for truth. Philosophically, wisdom consists in constant unwavering disposition to seek truth. Interpretatively a country that is geared towards continuous seeking for knowledge is the country that is on the path of development.

\subsection{Philosophy of Education as a Means of Good Life}

Wisdom or knowledge which is central in philosophy and philosophy of education is a necessary means of good life and national development. Philosophy is the search to know and understand the nature of man, creation and the world, knowledge, value and good life. Philosophy becomes significant as Adaeze (2003) noted, at the point where educators recognize the need to think clearly about what they are doing, and to relate what they are doing in the large context of man and society. Man's thoughts hold the key to his life and the society he lives in. Philosophy of education is a means of good life, when it gives directions as well as guidelines for good human relationships in any social setting, and calls for order through corrective suggestions and actions, aimed at bringing just living, co-habitation and prosperity for all.

Philosophy of education according to Oyedepo (2000) can awaken the talents and abilities of the people to formulate their longings as members of a society. It prescribes the ultimate centre of all things to realize in good life, for without good living man remains unhealthy and society suffers. The educational philosopher is the avantgarde (foresighted intellectual), and any nation that lacks such critical minds who can voice out against man's inhumanity to man, is only a step away from national development; for man lives in an inter-connected social whole where any form of injustice is contagious and threatens justice everywhere.

\subsection{Philosophy of Education in the Formulation of Educational Policy}

The relevance of educational philosophy in the formulation of Educational policy is that it enables the policy to capture the socio-political ideology of the particular society the policy is designed for. Educational philosophy does not only connect the societal ideology with the goals and objectives adoptable in education, it goes further to intermittently critique ideologies to ensure that such ideologies are worthwhile and fitting for society development. As an anchor, philosophy of education coordinates the various inputs from other discipline of education (psychology, sociology, history and economics, inter alia) into the policy as a complementary whole. Without such efforts, the whole of education and policy process will remain "a jig-saw puzzle whose bits and pieces hang together in a crazy quilt” (Akinpelu, 2005: p. 167).

Philosophy of education harnesses the goals and objectives needed for successful policy formulation. The mismatch between setting of goals and achievement of set goals, have been the reason behind the recorded failures of some national education policies. In order to dispel such mismatches, an educational philosophy ensures and maintains a perfect harmony between goals/objectives and their implementation. This will in turn enable the people for whom the policies are designed for to arrive at some degree of national development. Thus, it is the task of educational philosophy to necessitate flexibility and adaptation of educational policies in conformity with constant changes that affect human society and its ideology. This is to state that, for any nation's education practice to achieve its best for its educand, it has to be directed by sound philosophies. Supportive of the above, Amaele (2005) asserted that a well formulated policy on education built on a strong philosophical footing, is indeed a sure guide to getting things right in the world of education, and consequently in the development of a nation.

\subsection{Educational Philosophy in the Learner-Teacher Educational Practice}

In the activity of philosophizing, philosophy has a humbling effect on those who pursue it. It develops an open and questioning attitude in the learner and the nation in general. If a student understands philosophy of education critically, pondering its meaning for education and for himself, he can find it vital and thought provoking, thereby achieves deep intellectual developments. Engagement in philosophy of education makes a teacher and nation to continue to develop himself (the teacher) and itself (the nation) intellectually. A teacher or a nation can never truly teach, unless such a teacher or nation continues to learn himself or itself. A lamp can never light another lamp unless it continues to burn its own flames. This means that a teacher or a nation should continue to develop himself or itself intellectually if such a teacher or nation should assist in the intellectual development of 
its students and nation in general. This makes a country to move in accordance with the dynamic nature of the world, which would promote the spirit of virtuous character, and which strengthens tolerance that is lacking in many countries. When such challenge to development is surmounted, there will be a smooth development of the nation.

\section{Philosophical Implications and Recommendations}

\subsection{Philosophical Implications}

Regarding the issues raised in this paper about philosophy of education as a tool for national development, we could draw out the conclusion and the following implications are drawn: No nation can effectively resist change from within, when its political state as a national entity is changing.

This implies that the ideology or national goals of any nation has to respond to the criticism, analysis and clarifications of philosophy of education to achieve its national development. By employing logical rigor and criticisms in diffusing knowledge claims from the pool of opinion, philosophy of education provides the nation with a potent tool to confront reality. This implies that it is by the use of the analytic approach that the concepts and theories of development are given the necessary clarifications, to enable policy implementation sustain its needed logical accuracy and coherency.

If any education practice is based on sound philosophy it will promote good life or conduct, which in turn breeds peace and concord necessary for building a nation. This then implies that philosophy of education is an indispensable guide towards a crucial aspect of national development.

\subsection{Recommendations}

In view of what has been discussed based on the philosophical implications drawn from this paper, the following recommendations are proffered:

1) Philosophy of education practitioners should ally to translate educational theories to practice, since no nation can attain its national development without practicable educational theories.

2) Philosophers of education should not know less that as positive ideas can make a nation rich, negative ideas can greatly impoverish a nation and even destroy its legacies which have been built over the years. The dictum of Erasmus (1466-1546) is yet relevant that, "fruitless is the wisdom of him who has no knowledge of himself", and on the premise of Epictetus (60 AD-117 AD), "vail is the word of a philosopher that does not heal some wound."

3) Nothing deters the development of a nation more than the erroneous belief, that success can come the way of its citizens without hard work. The government should provide its educational philosophers with the required means and forum, so as to convince the citizens of the state that man's greatness lies in his power of thought. A man is the product of his thoughts. It is what he thinks that he becomes. Thus a nation that neglects its intellectual heritage, is not yet on the path of development.

\section{Conclusion}

This paper so far has attempted to demonstrate that philosophy of education is relevant to national development. It contended to aver that the aims and objectives of education are to bring about a civilized human being and societies of men and women. For education to achieve its intended aims and objectives, it needs a well fashioned philosophy of education. Arguably, if philosophy of education is to be relevant in the development of any form, it should take into great consideration its relevance to men and the practice of education, since men and education are central elements of development.

\section{References}

Adaeze, C. O. (2003). Introduction to Philosophy. Kaduna: Shomac Publications.

Akinpelu, J. A. (2005). Essays in Philosophy and Education. Lagos: Stirling-Horden Publishers (Nig.) Ltd.

Amaele, S. (2005). Understanding the Philosophy of Education. Ibadan: Bounty Press Ltd.

Babarinde, K., \& Farayola, J. A. (2005). Kantain Moral Test for Deregulating Education in Developing Societies. Nigerian Journal of Educational Philosophy, 12, 8-13. 
Donald, A. C. (1994). Fifty Readings in Philosophy (2nd ed.). New York: McGraw Hill.

Federal Government of Nigeria (2004). National Policy on Education (4th ed.). Yaba: NERDC Press.

Lavine, T. Z. (1984). From Socrates to Sartre: The Philosophic Quest. USA: Bantm Books.

Mango, H. (2011). Relevance of Philosophy of Education to National Development. Nigerian Journal of Educational Philosophy, 22, 1-14.

Ogundowole, E. K. (2004). Philosophy and Society. Akoka: Correct Counsels Limited.

Okoh, J. D. (1998). Philosophy of Education: The Basics. Owerri: Corporate Impressions.

Oroka, O. (2010). The Relevance of Philosophy of Education. Nigerian Journal of Educational Philosophy, 1, 1-5.

Oyedepo, D. (2000). Towards Mental Exploits. Lagos: Dominion Publishing House.

Reid, L. A. (1972). Philosophy and Theory of Education. In R. D. Archambault (Ed.), Philosophical Analysis and Education. London: Routledge and Kegan Paul.

Shaaba, M. M. (2010). The Relevance of Philosophy of Education to Good Governance. Nigerian Journal of Educational Philosophy, 1, 15-21.

Umo, U. C. (2005). Qualitative Primary Education in Nigeria. Journal of Qualitative Education, 1, 35-42. 
Scientific Research Publishing (SCIRP) is one of the largest Open Access journal publishers. It is currently publishing more than 200 open access, online, peer-reviewed journals covering a wide range of academic disciplines. SCIRP serves the worldwide academic communities and contributes to the progress and application of science with its publication.

Other selected journals from SCIRP are listed as below. Submit your manuscript to us via either submit@scirp.org or Online Submission Portal.
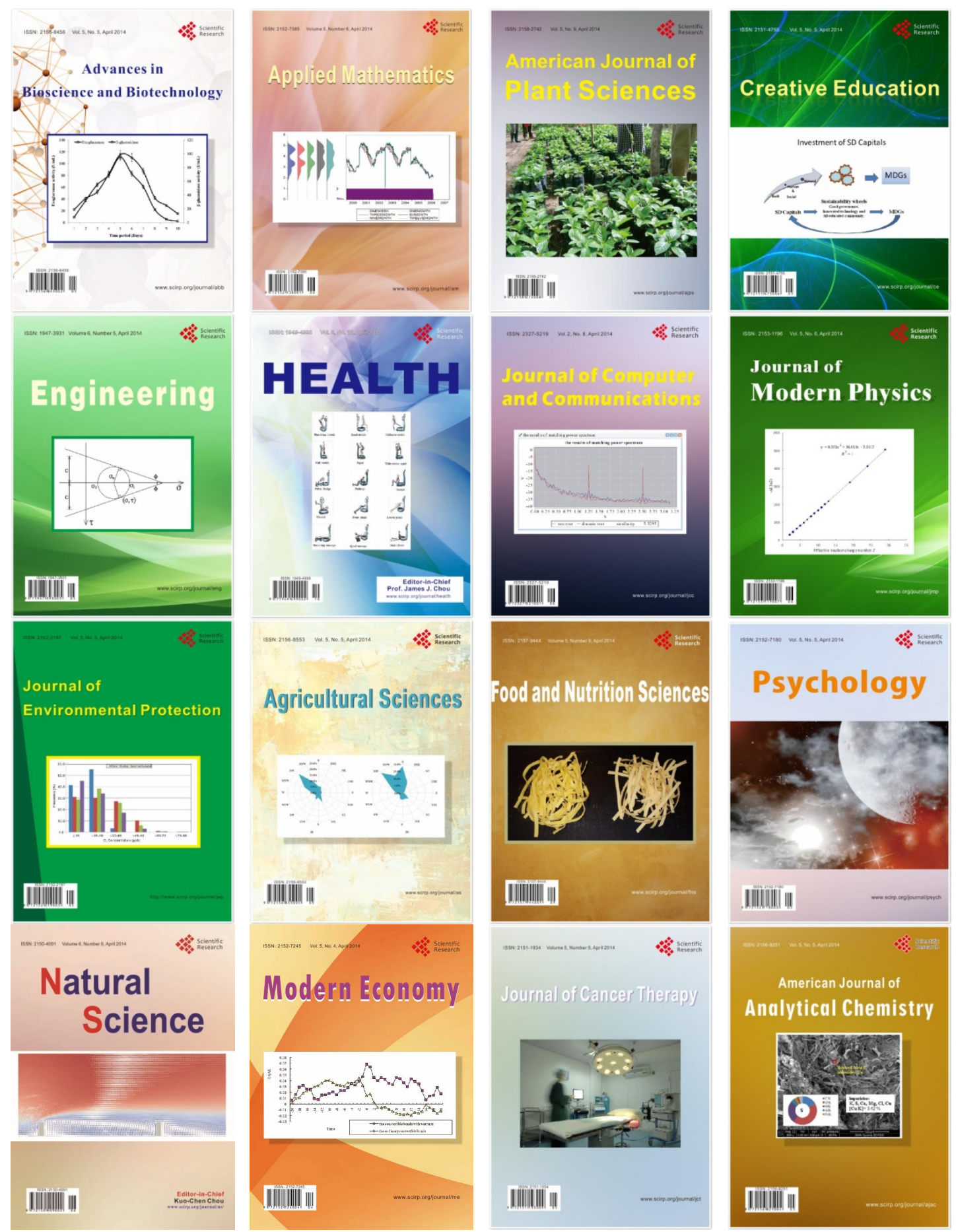